\title{
PSEUDOZARBA BIPARTITA (HERRICH-SCHÄFFER, 1850) (LEPIDOPTERA: NOCTUIDAE), A NEW GENUS AND SPECIES FOR THE FAUNA OF CROATIA
}

\section{TONI Koren}

Association Hyla, Lipovac I 7, HR-10000 Zagreb, Croatia (e-mail: toni.koren@hhdhyla.hr)

Koren, T.: Pseudozarba bipartita (Herrich-Schäffer, 1850) (Lepidoptera: Noctuidae), a new genus and species for the fauna of Croatia. Nat. Croat. Vol., 27, No. 2, 347-349, 2018, Zagreb.

During a survey of the moths of Lastovo Islands Nature Park, four specimens of the owlet moth Pseudozarba bipartita were observed and collected in Prgovo Polje on Lastovo island. This is the first report of the species P. bipartita in Croatia and the north-westernmost record in the Balkan Peninsula. The closest known populations are from Albania and Macedonia.

Key words: Dalmatia, Lastovo, moth survey, first record

Koren, T.: Pseudozarba bipartita (Herrich-Schäffer, 1850) (Lepidoptera: Noctuidae), novi rod i vrsta za faunu Hrvatske. Nat. Croat. Vol. 27, No. 2, 347-349, 2018, Zagreb.

Tijekom istraživanja noćnih leptira Parka prirode Lastovsko otočje, opažene su i sakupljene četiri jedinke sovice Pseudozarba bipartita na lokaciji Prgovo Polje, Lastovo. Ovo je prvi nalaz P. bipartita u Hrvatskoj i najsjeverozapadniji nalaz na Balkanskom poluotoku. Najbliže znane populacije su u Albaniji i Makedoniji.

Ključne riječi: Dalmacija, Lastovo, istraživanje noćnih leptira, prvi nalaz

In the last decades several quite extensive owlet moth (Noctuidae) surveys were carried out in different parts of the Croatia, like Dalmatia (Mladinov, 1974, 1975), Gorski Kotar (Kučınić et al., 1993), Rijeka and Kvarner areas (KučInIć, 1998). Recently, some small regions of Croatia were studied in more detail: Vransko jezero (SAvкоvić, 2001), island of Krk (Habeler, 2008) and Kopački Rit (Vignjević et al., 2010). Still, much of the mainland and most of the islands remain without any systematic surveys or any data in general.

The surveys of new and previously unexplored parts of Croatia commonly result in new country records like Synthymia fixa from the island of Šćedro (Koren \& LaUš, 2012), Antitype suda from Mt Biokovo (Mrnjavčić Vojvoda et al., 2014) and Chersotis rectangula from Mt Ivanjšćica (KoREN \& GoMBoc, 2015).

The genus Pseudozarba Warren, 1914 consists of at least 13 species, only one, however, Pseudozarba bipartita (Herrich-Schäffer, 1850) occurring in the southern parts of Europe. Other species inhabit the tropical and subtropical areas of Africa and Asia (FIBiger et al., 2009). Pseudozarba bipartita is distributed from northern Africa, through southern Europe, including south Spain, France, Italy, Malta, Greece and Bulgaria. In Asia it is known from Turkey and Israel (Fibiger et al., 2009). This species inhabits thermophilous habitats, maquis, ruderal areas and open steppes. Adults fly in two generations, from June to October. The early stages of this species are still unknown (FIBIGER et al., 2009). 
In 2018, we conducted the first preliminary moth survey of a previously almost totally unexplored island, Lastovo. Lastovo Island belongs to the central Dalmatian archipelago and is a part of the Dubrovnik-Neretva County. It is a medium sized island with an area of $46.87 \mathrm{~km}^{2}$. The climate on the island is Mediterranean, with moist winters and warm and dry summers.

Moths were surveyed using pyramidal UV light traps, with six traps used per locality. They were in operation usually for 4 hours after dusk. During the moth surveys, four specimens of P. bipartita (Fig. 1) were attracted to the light traps and collected in Prgovo Polje, Lastovo $\left(42^{\circ} 45^{\prime} 13.3^{\prime \prime} \mathrm{N} 16^{\circ} 55^{\prime} 00.0^{\prime \prime} \mathrm{E}\right)$ on $19^{\text {th }}$ July 2018 . The locality Prgovo Polje is one of several larger fields present on the island. It consists of arable fields (partly abandoned), small patches of dry grasslands and vineyards surrounded on both sides by Quercus ilex forests.

The collected specimens were set, identified, and stored in the private collection of the first author (Koren, Zagreb). The specimens were identified using (FIbIgER et al., 2009).

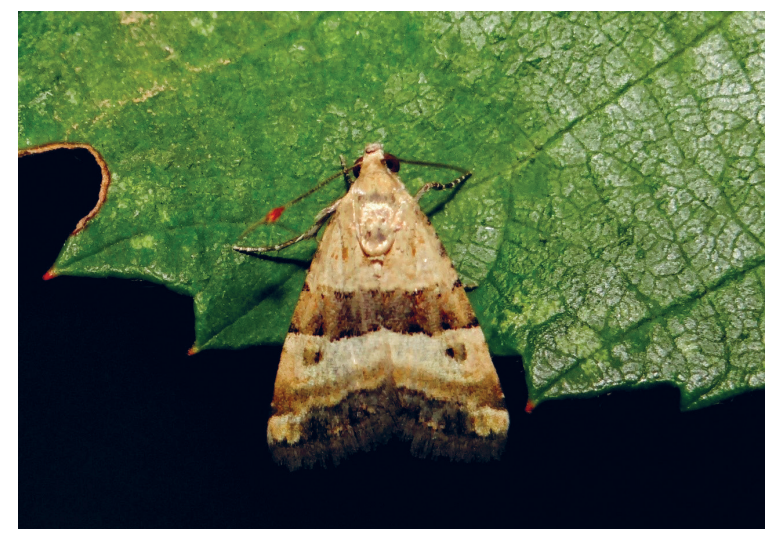

Fig. 1. Pseudozarba bipartita from Prgovo polje, Lastovo Island (photo by T. Koren).

Pseudozarba bipartita represents a new genus and species for the moth fauna of Croatia, and the north-westernmost record in the Balkan Peninsula. The closest known populations are located in the Former Yugoslavian Republic of Macedonia (Besнкоv, 2000), Bulgaria (GANev, 1982), Albania (Beshrov, 2018) and south-eastern Italy (Fibiger et al., 2009).

This record from Lastovo island shows the importance of visiting the previously unexplored areas, and the need for further surveys. While the butterfly fauna of the Adriatic islands is strongly correlated with the mainland fauna, and usually very depleted (Withrington \& VERovnik, 2008), it is possible that some of the Adriatic islands are the only suitable habitats for some moth species. Additional surveys of the island of Lastovo and the neighbouring islands should result in the finding of more localities for P. bipartita in Croatia.

I am grateful to Lastovo Islands Nature Park for financial support for the surveys, and to Ana Štih and Boris Lauš for company during field trips. 


\section{REFERENCES}

Beshкov, S., 2000: An annotated systematic and synonymic checklist of the Noctuidae of Bulgaria. Neue Entomologische Nachrichten 49, 1-300.

Beshкov, S., 2018: A contribution to knowledge of Balkan Leidoptera: new and rare Erebidae and Noctuidae for Albania, collected in 2016. Entomologist's Rec. J. Var. 130, 155-172.

Fibiger, M., Ronkay, L., Steiner, A. \& Zilli, A., 2009: Pantheinae, Dilobinae, Acronictinae, Eustrotiinae, Nolinae, Bagisarinae, Acontiinae, Metoponiinae, Heliothinae and Bryophilinae, Noctuidae Europaeae 8. Entomological Press, Sorø.

Ganev, J. 1982: Systematic and Synonymic list of Bulgarian Noctuidae. Phegea, 10(3), 145-160.

Habeler, H., 2008[2003]: Die Schmetterlinge der Adria-Insel Krk. Eine ökofaunistische Studie.

Koren, T. \& Gomboc, S., 2015: First record of Chersotis rectangula ([Denis \& Schiffermüller], 1775) in Croatia with new data for Chersotis multangula (Hübner, 1803) (Lepidoptera: Noctuidae). Šumarski list 139, 441-445.

Koren, T. \& Lauš, B., 2012: The first faunistic records of butterflies from two small Adriatic islands, Olib and Šćedro, Croatia. Entomologia Croatica 16, 115-124.

KučINIĆ, M., 1998: Faunističke i zoogeografske značajke sovica (Insecta, Noctuidae) Kvarnera s posebnim osvrtom na riječko područje. Radovi sa znanstvenog savjetovanja održanog povodom 120. godišnjice utemeljenja i 50. godišnjice osnutka Prirodoslovnog muzeja Rijeka, 523-538.

Kučınıć, M., ŠAšıć, M. \& BALEN, S., 1993: Faunističke, ekološke i zoogeografske karakteristike sovica (Noctuidae, Lepidoptera) Gorskog kotara. Šumarski list 117, 369-382.

Mladinov, L., 1974: Istraživanje faune sovica (Noctuidae) u Dalmaciji s osvrtom na štetne vrste. Inventarizacija biljnih bolesti i štetnika na graničnim područjima. Republički sekretarijat za poljoprivredu, prehrambenu industriju i šumarstvo SR Hrvatske 2, 1-10.

Mladinov, L., 1975: Istraživanje faune sovica (Lepidoptera, Noctuidae) u južnoj Dalmaciji. II. Inventarizacija biljnih bolesti i štetnika na graničnim područjima. Republički sekretarijat za poljoprivredu, prehrambenu industriju i šumarstvo SR Hrvatske 3, 27-38.

Mrnjavčić Vojvoda, A., Minoci, I., Vajdić, M. \& Kučınić, M., 2014: Antitype suda (Geyer, 1832) (Lepidoptera: Noctuidae), new species of noctuid fauna of Croatia, found in the Biokovo Nature Park. Natura Croatica 23, 379-388.

SAvкоvić, A., 2001: Sovice (Lepidoptera, Noctuidae) u području Vranskog jezera kraj Biograda, Hrvatska. Entomologia Croatica 5, 31-50.

Vignjević, G., Zahirović, Ž., Turić, N. \& Merdić, E., 2010: Moths (Lepidoptera: Heterocera) of Kopački rit Nature Park - Results of preliminary research. Entomologia Croatica 14, 17-32.

Withrington, D.K.J. \& Verovnik, R., 2008: Butterflies (Rhopalocera) of the Croatian islands. Entomologist's Gazette 59, 3-25. 
